\title{
Urszula Kluczyńska
}

Uniwersytet Medyczny im. Karola Marcinkowskiego w Poznaniu

\section{Bigoreksja, czyli kłopoty mężczyzn z ciałem}

\section{Wstęp}

Ocena wyglądu ciała w odniesieniu do szczupłości/otyłości jest zależna od kultury. Kultury biedniejsze, w których szczupłość kojarzona jest z biedą, niedożywieniem, chorobą, wyżej wartościują otyłość, odwrotnie wygląda to w krajach rozwiniętych, gdzie szczupłość kojarzona jest z samokontrolą, prestiżem i jest wyżej wartościowana (Rogan 1999, s. 20). Istnieją pewne społecznie skonstruowane wzorce ciała pożądanego i w odniesieniu do mężczyzn w naszej kulturze jest to mezomorficzna budowa, ciało szczupłe (pozbawione nadmiaru tłuszczu), a jednocześnie umięśnione.

Warto zaznaczyć, że obawy o adekwatność ciała w obliczu wymogów kulturowych dotyczą coraz młodszych osób obu płci. Podczas gdy dziewczęta określają mianem ideału ciała sylwetkę szczupłą, w przypadku chłopców jest to połączenie szczupłości i siły. Choć wyniki badań dotyczące poziomu satysfakcji z ciała wskazują na większe niezadowolenie z własnego ciała wśród dziewcząt niż chłopców (Duncan i in. 2006, s. 92), to należy zaznaczyć, że niezadowolenie z ciała w tych grupach dotyczy innych aspektów (Konstanski, Fisher, Gullone 2003, s. 190). Główną przyczyną niezadowolenia wśród dziewcząt jest postrzeganie siebie jako zbyt grubych, z kolei chłopcy określają się nie tylko jako zbyt otyłych, ale często jako zbyt wątłych ${ }^{1}$. Podczas gdy dziewczęta dążą do szczupłości, dla chłopców jest ona jedną z przyczyn braku satysfakcji z ciała (Konstanski, Fisher, Gullone 2004, s. 1322), gdyż młodzi mężczyźni chcieliby być więksi i bardziej umięśnieni, oraz cechuje ich wyższy poziom w skali dążenia do muskulatury (McCreary, Sasse 2000, s. 297-304). Badacze wskazują też na zależność między niezadowoleniem z własnego ciała i poczuciem własnej wartości wśród dziewcząt i chłopców (Cohane, Pope 2001, s. 373-379). Bigoreksja, czyli dysmorfia mięśniowa, pojawia się

\footnotetext{
1 Wyniki badań wskazują, że wśród młodych mężczyzn i chłopców, którzy są niezadowoleni z własnego ciała, połowa pragnie schudnąć, a połowa przytyć (Furnham, Calnan 1998, s. 58-72; Drewowski, Yee 1987, s. 626-634).
} 
około 19 roku życia, plus/minus 3 lata (Olivardia 2001, s. 256), a zatem dotyczy nie tylko dorosłych mężczyzn, ale również młodzieży².

\section{Dysmorfia mięśniowa}

Dysmorfia mięśniowa (muscle dysmorphia) jest zaburzeniem, które odnosi się głównie do męskiej cielesności - może dotyczyć kobiet, ale w dużo mniejszym zakresie (Chung 2001, s. 565-574; Pope i in. 1997, s. 548-557; Hitzeroth i in. 2001, s. 521-553; Pope i in. 2000). Trudno określić zasięg choroby, na rok 2000 badacze szacowali, że 100000 osób na całym świecie ${ }^{3}$ lub więcej, może spełniać formalne kryteria zaburzenia (Pope, Philips, Olivardia 2000). Zjawisko to, opisane przede wszystkim przez Harrisona G. Pope'a Jr. i Roberto Olivardię, oraz współpracowników określane było początkowo jako odwrócona anoreksja (reverse anorexia) lub potocznie jako bigoreksja (bigorexia). Dysmorfia mięśniowa została określona jako patologiczne zaabsorbowanie muskulaturą ciała, charakteryzujące się nadmierną troską o muskulaturę i dążeniem do zwiększenia masy bez zwiększenia poziomu tłuszczu w organizmie (Morgan 2000, s. 521-523). Osoby chore są niezadowolone z muskulatury (nie dotyczy to zatem wszystkich aspektów cielesności lub części ciała) i cechuje je rozbieżność pomiędzy ,ja” idealnym a „ja” realnym. Jednostki są przekonane, że nie są wystarczająco umięśnione, podczas gdy w rzeczywistości są zwykle ponadprzeciętnie zbudowane (Leone, Sedoryt, Gray 2005, s. 353).

Przekonanie, że ciało nie jest wystarczająco muskularne powoduje poczucie dyskomfortu lub pogorszenie funkcjonowania w obszarach społecznych, zawodowych i innych ważnych dziedzinach życia. Osoba dotknięta zaburzeniem często nie podejmuje aktywności w wyżej wymienionych obszarach, ponieważ całkowicie pochłaniają ją ćwiczenia i program diety oraz codzienne „cielesne” rytuały (Olivardia 2001, s. 254-255). Dyskomfort i obsesja związana z przekonaniem o niewystarczającej muskulaturze nie wynika jednak z próżności, nie polega na tym, że osoba chce wyglądać świetnie, chce wyglądać - w swym przekonaniu „możliwie do przyjęcia” (Pope, Philips, Olivardia 2000). Osoby z dysmorfią mięśniową unikają okoliczności, w których miałyby eksponować swe ciała, a jeśli znajdą się w takich sytuacjach, reagują dyskomfortem lub silnym niepokojem. Istotne jest także to, że jednostki dotknięte zaburzeniem kontynuują ćwiczenia, dietę lub konsumpcję różnych substancji pomimo świadomości negatywnych tego konsekwencji. Dysmorfia mięśniowa odróżnia się od innych zaburzeń wyłącznie koncentracją na byciu zbyt małym lub niewystarczająco umięśnionym, a nie jak w przypadku anoreksji nervosy na zbyt otyłym, lub na konkretnym aspekcie

2 Należy jednak podkreślić, że prowadzone badania dotyczące dysmorfii mięśniowej uwzględniają mężczyzn w wieku 18-30 lat.

3 Dysmorfia mięśniowa, mimo że opisana w Stanach Zjednoczonych, nie obejmuje wyłącznie tego obszaru. Szereg analiz wskazuje, że obejmuje Europę, Amerykę, Afrykę (zob. Pope i in. 2000, s. 1297-1301; Lipinski, Pope 2002, s. 163-171; Hitzeroth i in. 2001, s. 521-523). 
wyglądu jak w przypadku dysmorficznych zaburzeń ciała (Body Dysmofric Disorder) (Olivardia 2001, s. 254-255).

\section{Zachowanie osób z dysmorfią mięśniową}

Osoby z dysmorfią mięśniową przejawiają szereg diagnostycznych zachowań. Przede wszystkim koncentrują się na ćwiczeniach, jest to głównie podnoszenie ciężarów, mające wyrzeźbić umięśnioną sylwetkę, rygorystycznie przestrzegają diety, oraz kompulsywnie przeglądają się w lustrze (Olivardia 2001, s. 255). Pope, Philips i Olivardia $(2000$, s. 9) przytaczają wypowiedź respondenta, który przyznaje, że $90 \%$ swego czasu przeznacza na podnoszenie ciężarów, dietę i koncentrację na wyglądzie. Są to zachowania na tyle kompulsywne, że powodują, iż nie potrafi przejść obojętnie obok lustra, jeśli mija takowe, przegląda się w nim, ale tylko wówczas, gdy jest przekonany, że nikt nie patrzy. Według badań Olivardii i współpracowników mężczyźni z dysmorfią mięśniową oglądają się w lustrze od 9 do 12 razy dziennie, podczas gdy mężczyźni podnoszący ciężary, ale niedotknięci zaburzeniem - 3 razy (Olivardia, Pope, Hudson 2000, s. 1291-1296). Niektórzy mężczyźni oglądają się w lustrze nawet 50 razy dziennie, poświęcając na tę czynność około 40 minut każdego dnia. Bigorektycy oglądają się nie tylko w lustrach, ale także witrynach sklepowych, lusterkach kieszonkowych, a nawet sztućcach. Olivardia podaje przykład mężczyzny, który spowodował wypadek samochodowy, ponieważ podczas kierowania pojazdem sprawdzał wielokrotnie w lusterku, czy jego mięśnie nie wyglądają na zbyt małe. Zachowania te mają charakter kompulsywny i są tak silne, że mężczyźni nie mogą się od nich powstrzymać (Olivardia 2001, s. 255). Według badań mężczyźni z dysmorfią mięśniową rozmyślają o swej niewystarczającej muskulaturze ponad 5 godzin dziennie (Olivardia i in. 2000, s. 1291-1296; Pope i in. 2000, s. 92). Badacze przytaczają historię mężczyzny, który stwierdził, że jeśli spojrzy na siebie w lustrze i uzna, że wygląda niekorzystnie, zostaje cały dzień w domu i nigdzie nie wychodzi z obawy przed krytycznymi spojrzeniami. Dzieje się tak nawet wówczas, a może przede wszystkim, gdy zaplanuje towarzysko pozostałą część dnia - rezygnuje ze spotkań pod wpływem silnego lęku, stresu i obaw (Pope, Philips, Olivardia 2000, s. 84-85). Inny badany stwierdzil, że gdy spojrzy na siebie w lustrze przed wyjściem na randkę i uzna, że wygląda niewystarczająco dobrze - odwołuje spotkanie (Pope, Philips, Olivardia 2000, s. 93-94). Takie zachowanie powoduje narastającą izolację społeczną i zrywanie szeregu relacji.

Istotnym elementem zachowania osób dotkniętych dysmorfią mięśniową jest rezygnowanie z ważnych wydarzeń społecznych, zawodowych i rekreacyjnych na rzecz ćwiczeń i grafiku związanego z dietą (Pope i in. 1997, s. 548-557). Pewien mężczyzna nie uczestniczył w porodzie swojego dziecka, ponieważ w tym czasie miał zaplanowane ćwiczenia i obawiał się, że nawet jednorazowe pominięcie treningu będzie przyczyną skurczenia się mięśni. Z kolei pewien student nie wziął udziału w ważnym końcowym egzaminie, ponieważ czasowo pokrywał się on 
z treningiem (Olivardia 2001, s. 255). Inny respondent przyznał, że zawsze, gdy gdzieś wyjeżdża, analizuje okolicę, by zlokalizować najbliższą siłownię, w której będzie mógł ćwiczyć. Gdy pewnego razu wybierał się na wyspę, na której nie było siłowni, wysłał tam - nie bacząc na wysokie koszty - sprzęt do ćwiczeń, by po jego przylocie czekał już na niego w hotelu. Niektóre osoby w ogóle nie wyjeżdżają z domu w obawie o zaburzenie porządku ćwiczeń i diety (Pope, Philips, Olivardia 2000, s. 90).

Osoby cierpiące na bigoreksję bardzo zwracają uwagę na to, co jedzą, a przede wszystkim, jak wiele kalorii pochłaniają. Czynności związane z jedzeniem (planowanie, zakupy odpowiedniego jedzenia i suplementów, ważenie jedzenie, pakowanie w małe porcje do plastikowych woreczków) pochłaniają nawet 3 godziny dziennie (Pope, Philips, Olivardia 2000, s. 91). Chcąc przyjąć jak najwięcej odpowiednio dobranych składników, zwykle nie jedzą poza domem, ponieważ nie są w stanie określić kaloryczności potraw (Olivardia 2001, s. 255). Jedzenie jest związane z rygorystycznym rozkładem wchłaniania kalorii, a nie delektowaniem się smakiem potraw. Ponieważ przyjęcie odpowiedniej ilości kalorii, w celu ukształtowania ciągle niewystarczającej muskulatury, jest nieosiągalne bez koktajli proteinowych, są one nieodłącznym elementem diety. Olivardia podaje historię mężczyzny, który co 90 minut sporządzał na swym biurku w pewnej prawniczej firmie koktajl proteinowy, używając głośnego miksera, który przeszkadzał pozostałym pracownikom. Gdy został zmuszony, pod groźbą zwolnienia z pracy, do zaprzestania tego procederu, zrezygnował z pracy (Olivardia 2001, s. 255; Pope i in. 2000, s. 89). Inny respondent nie był w stanie połączyć czasu pracy z rygorystycznym terminarzem ćwiczen - wychodził z pracy godzinę wcześniej, a jego przerwa na lunch trwała około dwóch i pół godziny, w związku z czym został zwolniony. Zmienił zatem zawód i rozpoczął pracę jako osobisty trener (Pope, Philips, Olivardia 2000, s. 89). Koncentracja na ćwiczeniach i diecie nie tylko zaburza relacje towarzyskie, ale często uniemożliwia wykonywanie wyuczonego zawodu, nawet jeśli jest dochodowy. Mężczyźni często decydują się na pracę $\mathrm{w}$ siłowniach lub klubach sportowych, ponieważ - mimo że jest to praca gorzej płatna - nie koliduje z ich kompulsywnymi aktywnościami. Badacze przytaczają też historię mężczyzny, który pracował jako kucharz i szukał każdej okazji, by ćwiczyć w pracy, podnosił celowo garnki, wychodził do toalety, by zrobić choć pięćdziesiąt pompek. Mimo że czuł się zażenowany, gdy ktoś przyłapał go na tych czynnościach, nie mógł się od nich powstrzymać (Pope i in. 2000, s. 91).

Mężczyźni z dysmorfią mięśniową porównują wygląd innych osób ze swoim. Te porównania zawsze wypadają na niekorzyść chorego, którego zaburzone postrzeganie własnego ciała nie pozwala dokonać realistycznego oglądu. Badania wskazują na niski poziom wglądu, jaki posiadają jednostki dotknięte zaburzeniem. Mniej niż połowa mężczyzn z dysmorfią mięśniową miała doskonały lub dobry wgląd, połowa miała słaby wgląd, a osiem procent badanej grupy nie miało wcale wglądu. Oznacza to, że rozpoznanie ich rozmiaru ciała było niewłaściwe i nie można było ich przekonać, że wcale nie są zbyt mało umięśnieni (Olivardia, Pope, Hudson 2000, s. 1291-1296). Chorzy unikają zatem eksponowania swojego 
ciała w obawie przed negatywnym odbiorem innych osób. Nie są to więc osoby, które ukazują swój nagi lub niemal niezakryty tors - wręcz przeciwnie, starają się ukryć swe wciąż za mało umięśnione ciało pod wieloma warstwami odzieży, by wyglądało na większe (Olivardia 2001, s. 255-256). Rezygnują też z wizyt na basenie lub na plaży (Pope, Philips, Olivardia 2000, s. 9). Pewien badany przyznał, że podczas wizyt u lekarza nigdy nie zdejmuje koszulki, jeśli niezbędne jest badanie np. stetoskopem - lekarz wkłada go pod odzież (Pope, Philips, Olivardia 2000, s. 90). Pewien badany przyznał, że podczas podziału na drużyny nigdy nie zgodził się na przynależenie do grupy, która gra bez koszulek w obawie o ukazanie swego nagiego torsu. Jeśli miał grać w drużynie, która nie zakładała koszulek, zawsze znalazł wymówkę, by nie uczestniczyć w grze (Pope, Philips, Olivardia 2000, s. 92). Niebezpieczeństwem dla chorych jest izolacja społeczna, która może być wynikiem poświęcania całego dostępnego czasu na ćwiczenia, a zatem wycofanie się $\mathrm{z}$ relacji międzyludzkich, ale także unikanie ludzi ze względu na obawę o porównanie z innymi (Olivardia 2002, s. 61).

Dysmorfia mięśniowa powoduje także dyskomfort w relacjach z partnerami/ partnerkami. Badacze podają przykład mężczyzny, który unikał seksu z żoną, ponieważ nie chciał marnować energii na inne czynności niź ćwiczenia i rozwijanie masy mięśniowej. Ostatecznie ograniczył swą aktywność seksualną do dwóch stosunków miesięcznie. Inny badany unikał całowania się ze swoją dziewczyną w obawie o kalorie, które w jego przekonaniu mogła zawierać ślina (Pope i in. 2000, s. 90). Często, ze względu na nadmierne zaabsorbowanie czynnościami związanymi z budową muskulatury, partnerki/partnerzy zrywają relację z chorym (Pope i in. 2000, s. 9, 90).

Dla osób dotkniętych dystrofią mięśniową charakterystyczne jest kontynuowanie ćwiczeń nawet w sytuacji kontuzji. Badacze wskazują przykład mężczyzny, który ćwiczył mimo złamania kości, gdyż tak bardzo obawiał się spadku masy mięśniowej, że podejmował ćwiczenia mimo bólu i zagrożenia zdrowia. Konsekwencją takich działań była pięciotygodniowa rekonwalescencja. Po tym okresie czasu bez ćwiczeń mężczyzna był przekonany, że jego mięśnie są tak małe, że nie śmiał udać się do publicznej siłowni i zaczął ćwiczyć w domu (Pope i in. 2000, s. 93).

Osoby dotknięte dysmorfią mięśniową często maskują swą chorobę pragnieniem uprawiania sportu (Leone i in. 2005, s. 354). W ich przypadku budowa muskulatury nie jest „efektem ubocznym” sportowych poczynań, lecz powodem uprawiania sportu. Badacze wskazują, że trenerzy oczekują od zawodników sprawności fizycznej oraz muskulatury i jeśli sportowcy mają predyspozycje do dysmorfii mięśniowej, środowisko sportowe może sprzyjać rozwojowi zaburzenia. W związku z tym badacze sugerują, by przygotować trenerów oraz osoby pracujące ze sportowcami pod kątem diagnozowania zaburzenia.

Istnieje możliwość matematycznego opisu muskulatury mężczyzn. W tym celu stosuje się wskaźnik beztłuszczowej masy ciała (Fat-free mass index, FFMI), który oblicza się, wykorzystując dane dotyczące wzrostu, wagi osoby oraz procentowej zawartości tłuszczu w organizmie. Wskaźnik o wartości 20 opisuje mężczyznę przeciętnie umięśnionego, wartość 23 dotyczy opisu mężczyzny, którego 
muskulatura jest widoczna. Według analiz Eleny M. Kauri i współpracowników (2009, s. 193) nie można uzyskać poziomu wskaźnika FFMI powyżej 26 w sposób naturalny, a przynajmniej poprzez ograniczenie się do ćwiczeń i diety, bez wspomagania sterydami anabolicznych (Pope, Philips, Olivardia 2000, s. 35). Badania wykazują, że chorzy na bigoreksję często przekraczają wartość 26 (Mosley 2009, s. 193). W związku z tym można wywnioskować, że sięgają po sterydy anaboliczne, które umożliwiają osiągnięcie lepszych rezultatów w krótszym czasie (Olivardia 2001, s. 256). Osoby z dystrofią mięśniową, wchodząc w subkulturę kulturystów, dowiadują się, że sterydy dadzą im to, czego suplementy nie potrafią - szybszy i większy przyrost mięśni. Największym niebezpieczeństwem jest uzależnienie od tych szkodliwych substancji, na które chorzy są szczególnie podatni, a także zagrożenie zdrowotne, jakie niesie za sobą stosowanie sterydów (Pope, Philips, Olivardia 2000).

\section{Etiologia dysmorfii mięśniowej}

Etiologia dysmorfii mięśniowej nie jest znana. Hipotezy dotyczące przyczyn zaburzenia opierają się na modelu biopsychospołecznym (Olivardia, Pope, Hudson 2000, s. 548-557; Pope, Philips, Olivardia 2000). Część badaczy sugeruje, że dysmorfia mięśniowa pojawiła się jako efekt czynników socjokulturowych (Pope i in. 1997), czyli oczekiwań i presji społecznej dotyczącej oczekiwań wyglądu ciała (Pope, Philips, Olivardia 2000; Olivardia 2001; Leit, Gray, Pope 2002, s. 334-338). Olivardia stawia hipotezę, że obok czynników społeczno-kulturowych przyczyny występowania dysmorfii mięśniowej mogą być związane z predyspozycjami biologicznymi lub genetycznymi (Olivardia 2001, s. 256). Lantz, Hera i Mayhew opisują dysmorfię mięśniową jako wynik wzajemnego oddziaływania między niskim poczuciem własnej wartości, niezadowolenia z ciała lub jego błędnego postrzegania w połączeniu z oddziaływaniem czynników biologicznych i społecznych (Lantz i in. 2001, s. 71-86). Autorzy sugerują, że rozwój dysmorfii mięśniowej wynika bezpośrednio z niezadowolenia z ciała (Lantz i in. 2001). Z kolei Frederick Grieve (2007, s. 63-80) proponuje model, który uwzględnia czynniki biologiczne (BMI), społeczne i funkcjonowanie psychologiczne oraz udział w sportach. Wskazuje on na trzy najważniejsze zmienne: zniekształcenie w postrzeganiu ciała, niezadowolenie z własnego ciała i zinternalizowany ideał wizerunku ciała, które w połączeniu z perfekcjonizmem, niskim poczuciem własnej wartości, presją mass mediów, udziałem w sporcie, tworzą warunki sprzyjające rozwojowi dystrofii mięśniowej.

Olivardia zwraca uwagę, że dysmorfia mięśniowa współwystępuje z innymi zaburzeniami psychicznymi. Wraz ze współpracownikami dowiódł w badaniach na grupie mężczyzn, że 29\% osób z dysmorfią mięśniową chorowało na zaburzenia odżywiania, 58\% dotyczył w przeszłości problem z zaburzeniami nastroju (Olivardia i in. 2000, s. 1291-1296). Osoby z dysmorfią mięśniową mają także niskie poczucie własnej wartości (Pope i in. 2000; McCreary, Sasse 2000, s. 297-304) oraz 
są bardziej kompulsywne (Olivardia 2001, s. 257). Ponieważ osoby z dysmorfią mięśniową stosują często nielegalne substancje, które mają dopomóc w zwiększeniu muskulatury (sterydy, narkotyki), są narażone na powikłania zdrowotne związane z przyjmowaniem tych produktów.

\section{Klasyfikacja choroby}

Trwa dyskusja dotycząca właściwego zaklasyfikowania dysmorfii mięśniowej, istotnego ze względu na proces prewencji, diagnozy i leczenia (Chandler i in. 2009, s. 151). Dysmorfia mięśniowa została zaklasyfikowana jako podtyp dysmorficznych zaburzeń ciała (Pope, Katz 1994, s. 375-382), część badaczy wskazuje na powiązania z zaburzeniami obsesyjno-kompulsywnymi (Maida, Armstrong 2005; Chandler i in. 2009, s. 150; Pope i in. 2000, s. 97) lub sugeruje, że bigoreksja powinna być klasyfikowana jako zaburzenie odżywiania (Grieve 2007, s. 63-80; Grieve, Helmick 2008, s. 288; Goodale i in. 2001 s. 260-266). Pojawiły się także głosy, że nie powinno się włączać dysmorfii mięśniowej do istniejących grup chorób, lecz stworzyć samodzielny opis zaburzenia (Chandler i in. 2009, s. 151).

Denise M. Maida, Sharon L. Armstrong (2005, s. 73-91) poddały analizie relację między dysmorfią mięśniową a innymi zaburzeniami i wskazały na związek choroby z zaburzeniami obsesyjno-kompulsywnymi, dysmorficznymi zaburzeniami ciała, oraz niezadowoleniem z własnego ciała. Autorki sugerują, że dysmorfia mięśniowa jest bliższa zaburzeniom obsesyjno-kompulsywnym niż zaburzeniom somatyzacyjnym (Maida, Armstrong 2005, s. 85).

Grieve (2007, s. 63-80) twierdzi, że choroba obejmuje zarówno zaburzenia lękowe i zaburzenia odżywiania oraz że istnieje wiele podobieństw między kryteriami diagnozy dysmorfii mięśniowej, anoreksji nervosy i bulimii nervosy. Badacz zwraca uwagę, że początkowo zaburzenie zostało określone jako „odwrócona anoreksja" (Pope, Katz, Hudson 1993, s. 406-409) właśnie ze względu na podobieństwo do anoreksji nervosy, a ponadto wiele osób z dystrofią mięśniową dotyczył wcześniej problem zaburzeń odżywiania. Ponadto w przypadku obu zaburzeń samoocena jest silnie związana z kształtem i rozmiarem ciała. Im ciało jest bliższe społecznie propagowanemu i nagradzanemu ideałowi, tym wyższa samoocena. Mężczyźni dążą zatem do uzyskania mezomorficznej budowy ciała, o maksymalnej ilości mięśni i minimalnej ilości tłuszczu. Zarówno dysmorfia mięśniowa, jak i anoreksja nervosa oraz bulimia nervosa charakteryzują się chronicznym zaabsorbowaniem ciałem i dążeniem do jego zmiany poprzez odpowiednią dietę i ćwiczenia. Podobieństwem jest także zaburzenie postrzegania siebie, osoby chore na anoreksję widzą się ciągle jako niewystarczająco szczupłe, podczas gdy osoby chore na dysmorfię mięśniową jako niewystarczająco umięśnione (Grieve 2007, s. 65). Zarówno w przypadku anoreksji, jak i bigoreksji osoby dążą do fizycznej autodestrukcji. Podejmowanie ćwiczeń pomimo bólu i kontuzji, ciągłe stosowanie niskotłuszowej i wysokoproteinowej diety mimo głodu, stosowanie sterydów - to zachowania niszczące organizm (Pope, Philips, Olivardia 
2000, s. 11). Grieve wskazuje także na analogię dystrofii mięśniowej do innego zaburzenia odżywiania - zespołu kompulsywnego objadania się (binge eating disorder). Mężczyźni pochłaniają bowiem ogromną liczbę kalorii, także w specjalnych koktajlach (ponieważ zwykłe pożywienie często nie dostarczyłoby takiej ilości kalorii), które następnie „przekuwają” w mięśnie (Grieve 2007, s. 65-66). Istotną różnicą pomiędzy dystrofią mięśniową i anoreksją jest to, że chorzy na anoreksję, którzy koncentrują się na pozbyciu tłuszczu z organizmu, angażują się w patologiczne zachowania związane przede wszystkim z odżywianiem i na drugim miejscu stawiają ćwiczenia. Z kolei osoby z dysmorfią mięśniową, dążąc do rozwoju muskulatury, koncentrują się na ćwiczeniach i poddają swe ciała wielogodzinnym treningom, podporządkowując im restrykcyjną dietę. Inny zatem nacisk położony jest na te dwa współwystępujące zachowania we wskazanych zaburzeniach (Maida, Armstrong 2005, s. 74; Olivardia 2001, s. 255). Maida i Amstrong wskazują na jeszcze jedną istotną różnicę między dystrofią mięśniową i zaburzeniami odżywiania dotyczącą etiologii choroby. Podczas gdy w przypadku zaburzeń odżywiania badacze odkryli istotny wpływ traumy przeżytej w dzieciństwie (wykorzystywanie fizyczne, emocjonalne lub seksualne) i problemach w rodzinie, chorych na bigoreksję ten problem nie dotyczył, choć należy zaznaczyć, że w dzieciństwie odczuwali pewne zawstydzenie lub zażenowanie wynikające $\mathrm{z}$ niedoskonałości własnego wyglądu, np. wyśmiewanie ze względu na tuszę lub wątłość (Pope, Philips, Olivardia 2000, s. 15). Niektórzy badani z dysmorfią mięśniową wskazali, że będąc dziećmi, byli bardzo drobni lub otyli i z tego powodu byli gnębieni przez rówieśników. W związku z tym skoncentrowali się na swoim ciele i wyglądzie, by zakończyć prześladowania (Olivardia 2001, s. 256).

\section{Diagnoza i proces leczenia dysmorfii mięśniowej}

Przebieg leczenia dysmorfii mięśniowej opiera się gównie na zaleceniach dotyczących leczenia zaburzeń obsesyjno-kompulsywnych, dysmorficznych zaburzeń ciała i zaburzeń odżywiania (Olivardia 2001, s. 257). Olivardia zwraca uwagę, że osoby chorujące na dysmorfię mięśniową rzadko zwracają się do specjalistów i podejmują leczenie. Częściej szukają pomocy ze względu na towarzyszącą zaburzeniu depresję lub nadużywanie szkodliwych substancji (choć raczej nie sterydów). Chorzy nie podejmują prób szukania pomocy, ponieważ wiązałoby się to z zakłopotaniem związanym z przyznaniem się do niedoskonałości swojego ciała, ale podważone zostałoby również ich poczucie męskości, gdyby mieli ujawnić komuś swój problem (Olivardia 2001, s. 257).

Podczas gdy osoby chore na anoreksję bywają zmuszane do poszukiwania pomocy ze względu na wyniszczenie organizmu i groźbę śmierci, osoby dotknięte dysmorfią mięśniową wydają się być okazami zdrowia i robią wrażenie osób prowadzących zdrowy, aktywny styl życia (Dawes, Mankin 2004, s. 24-25). By pomóc w diagnozie problemu, Pope, Philips i Olivardia stworzyli piętnastopunktową listę, której twierdzące odpowiedzi mogą sugerować różny poziom bigoreksji. 
Mężczyźni z niewielkim poziomem dysmorfii mięśniowej zgadzają się z czteroma lub pięcioma stwierdzeniami, jeśli osoba zgadza się z połową twierdzeń, oznacza to, że bigoreksja ma znaczący wpływ na jej codzienne funkcjonowanie. Lista dotyczy następujących kwestii: częstotliwości martwienia się o bycie wystarczająco smukłym i muskularnym; rezygnowania z atrakcyjnych spotkań i aktywności ze względu na zaplanowane ćwiczenia; negatywnego wpływu ćwiczeń na możliwości rozwoju kariery lub rezygnację z pracy; bycia na wysokoprorteinowej i niskotłuszczowej diecie wspomaganej suplementami w celu zwiększenia masy mięśniowej; wydawania dużej sumy pieniędzy na suplementy i substancje mające polepszyć muskulaturę; rezygnowania $\mathrm{z}$ wizyt $\mathrm{w}$ restauracjach, proszonych obiadach ze względu na stosowaną dietę; unikania sytuacji, w których inni mogą widzieć ciało (plaża, przebieralnia, publiczny prysznic) ze względu na obawę o niewystarczająco muskularne ciało; noszenia kilku warstw odzieży, by wyglądać na lepiej zbudowanego; celowe wybieranie odzieży, w której wygląda się na większego; częstego mierzenia obwodu poszczególnych części ciała (klatki piersiowej, bicepsa itp.); kontynuowania ćwiczeń pomimo urazów i kontuzji z obawy przed utratą masy mięśniowej; stosowania leków (legalnych i nielegalnych) w celu zwiększenia muskulatury; częstego porównywania się do innych w obawie, że jest się mniej umięśnionym niż oni; poczucia zazdrości przez dłuższy czas po ujrzeniu kogoś, kto jest bardziej muskularny (Pope i in. 2000, s. 88-89).

Ponadto użyteczna w diagnozowaniu zaburzeń w kierunku zaburzeń ciała u mężczyzn (a także postrzegania atrakcyjności męskiego ciała zarówno przez mężczyzn jak i kobiety) może być "Siatka wizerunków kulturystów” - Bodybuilder Image Grid (Hildebrandt, Langenbucher, Schlundt 2004, s. 171). Postaci zaprezentowane na siatce różnią się poziomem masy mięśniowej i zawartością tłuszczu w organizmie. Wykorzystanie narzędzia wiąże się z zadaniem mężczyznom czterech poleceń: wskazania wizerunku, który zdaniem badanego odzwierciedla jego aktualny wygląd ciała; wskazanie wizerunku, który przedstawia zdaniem badanego idealny wygląd ciała; wskazanie najbardziej atrakcyjnego typu ciała; wskazanie najbardziej atrakcyjnego wizerunku ciała dla płci przeciwnej.

Proces leczenia powinien obejmować dążenie do zmniejszenia czasu przebywania na siłowni, a także zaprzestania stosowania sterydów, co jednak łączy się z największą obawą chorych - utratą masy (Olivardia 2001, s. 257). Istotnym elementem procesu leczenia jest psychoedukacja, która powinna obejmować edukację w zakresie właściwego żywienia, niebezpieczeństwa stosowania sterydów i ukazać, że wizerunki prezentowane w mediach nie zawsze są dokładnym odwzorowaniem wyglądu ludzi lub właściwą sugestią, jak ludzie powinni wyglądać. W toku leczenia jest obserwowanie rozwoju dysmorfii mięśniowej i wieku, w jakim się pojawiła. Olivardia podkreśla także, że w toku psychoterapii warto skupić się na powodach lub doświadczeniach, które wpłynęły na skupieniu się przez jednostkę na wyglądzie ciała. Autor wskazuje także, że w procesie leczenia można wykorzystać poznawczo-behawioralne techniki stosowane $\mathrm{w}$ leczeniu dysmorficznych zaburzeń ciała oraz leczenie farmakologiczne. $W$ toku pracy z pacjentem istotnym aspektem jest także zaprzestanie stosowania przez chorego sterydów. 
Klinicyści powinni także określić idealny wizerunek ciała chorego i oszacować, na ile jest on realistyczny (Olivardia 2001, s. 257-258). Celem leczenia powinno być zwiększenie wglądu i umiejętności realistycznej oceny ciała ${ }^{4}$.

\section{Zakończenie: dysmorfia mięśniowa i męskość}

Coraz częściej kłopoty z ciałem, które były określane jako typowo kobiece, stają się domeną mężczyzn. Mężczyźni, koncentrując się na ciele, uczynili zeń istotny element własnej tożsamości i poczucia męskości. Z perspektywy psychologicznej osoby dotknięte dysmorfią mięśniową charakteryzuje niskie poczucie własnej wartości. Dążenie do muskulatury może zatem stanowić próbę kompensacji poczucia bycia niewystarczająco „męskim” (Pope, Philips, Olivardia 2000).

Według badań, już od lat 90. XX wieku coraz większa liczba mężczyzn deklaruje niezadowolenie ze swojego ciała lub poszczególnych partii ciała (McCaulay $\mathrm{i}$ in. 1988, s. 381-390; Mishkind i in. 1986, s. 545-562). Według analiz Olivardii (2002, s. 59-63) poziom niezadowolenia mężczyzn z wyglądu potroił się w przeciągu niespełna 30 lat. $11 \%$ procent mężczyzn (i 15\% kobiet) w badaniach przeprowadzonych w 1996 roku oddałoby 5 lat życia, gdyby mogli dzięki temu ważyć tyle, ile chcieliby, $17 \%$ mężczyzn (i $24 \%$ kobiet) oddałoby więcej niż 3 lata życia (Garner 1997, s. 34). Badacze zwracają uwagę, że mężczyźni w takim samym stopniu jak kobiety odczuwają niezadowolenie z własnego wyglądu, a w odniesieniu do pewnych partii ciała - klatki piersiowej - nawet je przewyższają (Pope, Philips, Olivardia 2000, s. 27). Mężczyźni ulegli nakazom, zakazom i oczekiwaniom wobec ciała, które wcześniej dotyczyły głównie kobiet, i jak twierdzą badacze - współcześnie nawet 25-30\% zaburzeń odżywiania dotyczy mężczyzn (Anderson, Cohn, Holbrook 2000). W przeprowadzonych badaniach prawie połowa respondentów była całkowicie lub bardzo niezadowolona za swojego wyglądu, 74\% mężczyzn uważało, że są za grubi oraz że czują się skrajnie niekomfortowo, jeśli nie mogą ćwiczyć przez tydzień, a połowa przyznała, że stosuje sterydy (Pope i in. 2000, s. 92). Ciało stało się możliwością, ale jednocześnie pułapką. Niezadowolenie z własnego ciała przez coraz większą ilość mężczyzn nie jest jednak zawieszone w próżni, kluczową rolę odgrywa tło społeczno-kulturowe (Kostanski i in. 2003, s. 1322).

\section{Literatura:}

Anderson A., Cohn L., Holbrook T., 2000, Making weight, Carlsbad, CA: Gurze Books.

Chandler C.G., Grieve F.G., Derryberry W.P., Pegg P.O., 2009, Are Anxiety and Obsessive-Compulsive Symptoms Related to Muscle Dysmorphia, "International Journal of Men's Health" No. 8.

4 Szerzej na temat leczenia dysmorfii mięśniowej: pracy z pacjentem, wskazówki dla psychologów, terapeutów, osób mogących pracować z grupą potencjalnie zagrożoną występowaniem zaburzenia (sportowcami) w: (Olivardia 2001; Leone i in. 2005; Grieve i in. 2009, s. 306-314). 
Chung B., 2001, Muscle dysmorphia; a critical review of the proposed criteria, "Perspect Biol Med." No. 44.

Cohane G.H., Pope H.G. Jr., 2001, Body Image In Boys: A Review of the Literature, "International Journal of Eating Disorders" Vol. 29, No. 4.

Dawes J., Mankin T., 2004, Muscle Dysmorphia, "Strength Cond. Journal" Vol. 26, No. 24-25.

Drewowski A., Yee D.K., 1987, Men and body image: Are males satisfied with their body weight?, "Psychosomatic Medicine" Vol. 49.

Duncan M.J., Al-Nakeeb Y., Nevill A.M., Jones M.V., 2006, Body dissatisfaction, body fat and physical activity in British children, "International Journal of Pediatric Obesity" Vol. 1, No. 2.

Furnham A., Calnan A., 1998, Eating Disturbance, Self-Esteem, Reason for Exercising and Body Weight Dissatisfaction in Adolescent Males, "European Eating Disorders Review" Vol. 6, No. 1.

Garner D.M., 1997, The 1997 Body image, "Psychology Today" Vol. 30.

Goodale K.R., Watkins P.L., Cardinal B.J., 2001, Muscle dysmorphia: A new form of eating disorder?, "American Journal of Health Education" Vol. 32.

Grieve F.G., 2007, A conceptual Model of Factors Contributing to the Development of Muscle Dysmorphia, "Eating Disorders" Vol. 15.

Grieve F.G., Truba N., Bowersox S., 2009, Etiology, Assessment, and Treatment of Muscle Dysmorphia, "Journal of Cognitive Psychotherapy: An International Quarterly" Vol. 23.

Grieve R., Helmick A., 2008, The Influence of Men's Self-Objectification on Drive for Muscularity: Self-Esteem, Body Satisfaction and Muscle Dysmorphia, "International Journal of Men's Health" Vol. 7.

Hildebrandt T., Langenbucher J., Schlundt D.G., 2004, Muscularity concerns among men: development of attitudinal and perceptual measures, "Body Image" Vol. 1.

Hitzeroth V., Wessels Ch., Zungu-Dirwayi N., Oosthuizen P., Stein D.J., 2001, Muscle dysmorphia: A South African sample, "Psychiatry and Clinical Neurosciences" Vol. 55.

Kostanski M., Fisher A., Gullone E., 2003, Conceptualising body image: The inherent difficulties in analysis, "Australian Journal of Psychology" Vol. 55.

Kouri E.M., Pope H.G. Jr., Katz D.L., Oliva P., 1995, Fat-free mass index in users and nonusers of anabolic androgenic steroids, "Clinical Journal of Sport Medicine" Vol. 5.

Leone J.E., Sedoryt E.J., Gray K.A., 2005, Recognition and Treatment of muscle Dysmorphia and Related Body Image Disorders, "Journal of Athletic Training" Vol. 40, No. 4.

Lipinski J.P, Pope H.G. Jr., 2002, Body ideal in young Samoan men: comparasion with men in North America, "International Journal of Men's Health" Vol. 1.

Maida D.M., Amstrong S.L., 2005, The Classification of Muscle Dysmorphia, "International Journal of Men's Health" Vol. 4.

McCaulay M., Mintz L., Glenn A.A., 1988, Body Image, Self-esteem, and Depression-Proneness: Closing the Gender Gap, "Sex Role" Vol. 18.

McCreary D., Sasse D., 2000, An exploration of the driver for muscularity in adolescent boys and girls, "Journal of American Collage Health" Vol. 48.

Mishkind M.E. i in., 1986, Embodiment of Masculinity, "American Behavioral Scientist" Vol. 29.

Morgan J.F., 2000, From Charles Atlas to Adonis complex - fat is more than feminist issue, "The Lancet".

Mosley P.E., 2009, Bigorexia: Bodybuilding and Muscle dysmorphia, "European Eating Disorders Review" Vol. 17.

Olivardia R., 2002, Body Image Obsession in Men, "Healthy Weight Journal” Vol. 16. 
Olivardia R., 2001, Mirror, Mirror on the Wall, Who's the Largest of Them All? The Features and Phenomenology of Muscle Dysmorphia, "Harvard Review Psychology" Vol. 9, No. 5.

Olivardia R., Pope H.G. Jr., Hudson J.I., 2000, Muscle dysmorphia in male weightlifters: a case control study, "American Journal of Psychiatry" Vol. 157.

Pope H.G. Jr, Gruber A.J., Choi P.Y.L., Olivardia R., Phillips K.A., 1997, Muscle dysmorphia: an underrecognized from of body dismorfic disorder, "Psychosomatics" Vol. 38.

Pope H.G. Jr., Gruber A.J., Mangweth B. i in., 2000, Body image perception in three countries, "American Journal of Psychiatry" Vol. 157.

Pope H.G. Jr., Katz D.L., Hudson J.I., 1993, Anorexia nervosa and "reverse anorexia” among 108 male bodybuilders, "Comprehensive Psychiatry" Vol. 34.

Pope H.G. Jr., Katz D.L., 1994, Psychiatric and medical effect of anabolic androgynies steroids. A controlled study of 160 athletes, "Archives of General Psychiatry" Vol. 51.

Pope H.G. Jr., Philips K.A., Olivardia R., 2000, The Adonis Complex: the secret crisis of male body obsession, Free Press, New York.

Rogan S., 1999, Body Image. Understanding body dissatisfaction in men, women and children, Routledge, London and New York.

\section{Summary}

Bigorexia: men's trouble with the body

The essence of this article is an attempt to answer the questions about contradictory discourses of male corporeal identity related to the gym practices. This article explores the role that gym plays in the formation and negotiation of masculinities for men.

Keywords

masculinity, body, identity, bigorexia

\section{Słowa kluczowe}

męskość, ciało, tożsamość, bigoreksja 